\title{
OPEN Degradation of soil quality by the waste leachate in a Mediterranean semi-arid ecosystem
}

\author{
Sh. Yeilagi, Salar Rezapour ${ }^{\bowtie}$ \&. Asadzadeh
}

The assessment of soil quality indices in waste leachate-affected soils is vital to understand the threats of land quality degradation and how to control it. In this respect, a study was conducted on the effects of uncontrolled landfill leachate on soil quality index (SOI) in calcareous agricultural lands using 28 soil variables. Using the total data set (TDS) and minimum data set (MDS) approaches, the SOI was compared between leachate-affected soils (LAS) and control soils by the integrated quality index (IQI) and nemoro quality index (NOI) methods. The results revealed that LAS were significantly enriched by soil salinity-sodicity indices including electrical conductivity (EC), sodium adsorption ratio (SAR), and exchangeable sodium percentage (ESP), fertility indices including total $N$, available $P$ and $K$, organic carbon, and cation exchange capacity (CEC), exchangeable cations ( $\mathrm{Ca}, \mathrm{Mg}, \mathrm{K}$, and $\mathrm{Na}$ ), the available and total fractions of heavy metals $(\mathrm{Zn}, \mathrm{Cu}, \mathrm{Cd}, \mathrm{Pb}, \mathrm{Ni})$. After the leachate got its way into the soil, the values of IQI and NOI were dropped ranging 5-16\% and 6.5-13\% for the TDS approach and 5-15.2\% and 7.5-12.2 for the MDS approach, respectively. Clearly, the data showed that soil quality degradation was encouraged and stimulated by the leachate. Among the different models of SQI applied in the present study, IQI determined by MDS was the optimal model to estimate soil quality and predict crop yields given the analysis of the correlations among the SOI models, the correlations between the SOI models and wheat yield, and sensitivity index values.

Presently, one of the most important environmental challenges of the world posed by rapid population growth and urbanization is the generation of a high volume of municipal solid waste (MSW) that can seriously threaten the health of soil-water-plant-human systems. Based on the World Bank Group, the global generation of MSW amounted to 1.3 billion tons year ${ }^{-1}$ in 2018 , expected to reach approximately 2.2 billion tons by $2025^{1}$. This huge volume of waste can pose a great challenge mainly in low- and middle-income countries and developing nations. In general, MSW is generated from various sources, e.g., industrial, agricultural, service, commercial, and household activities or everyday items discarded by the public. The quality and composition of MSW vary by activity type and involves plastic, food waste, inorganic salts, glass, paper, building and electronic wastes, metals, and organic fractions ${ }^{2}$. As a result of biodegradation and various physical, chemical, and biological reactions occurring in MSW, leachate is produced as a by-product. Leachate is a dark brown liquid with a stinking smell that is excreted inside MSW and contains soluble and suspended material. The leachate composition contains inorganic and soluble organic and inorganic compounds, nutrients, suspended particles, heavy metals, and many hazardous chemicals, causing significant damage to both natural and agricultural ecosystems when released in an untreated and uncontrolled manner ${ }^{3,4}$. The rate of leachate production, its volume, and its properties depend on various factors, e.g., the composition of waste material, its particle size, degree of waste compaction, waste moisture and temperature, the amount of rainfall, and the quantity and quality of biochemical that occur in the degradation stages of the $\mathrm{MSW}^{2,4}$.

Several studies have found the negative effects of waste leachate on soil quality due to the presence of high content of nutrients, heavy metals, and soluble salts in the leachate ${ }^{3,4}$. For example, a range of approximately 1000-3000 mg L ${ }^{-1}$ for ammoniacal nitrogen was reported in leachates from different parts of the world ${ }^{5}$ and ranges of $0.1-40 \mathrm{mg} \mathrm{kg}^{-1}, 20-1500 \mathrm{mg} \mathrm{kg}^{-1}$, and $15-1300 \mathrm{mg} \mathrm{kg}^{-1}$ were found for $\mathrm{Cd}, \mathrm{Cr}$, and $\mathrm{Ni}$ of leachates of the US, respectively ${ }^{6}$. The upper range of these concentrations is far beyond their acceptable ranges. However, few studies have investigated the impacts of leachate on the degradation of soil quality. 
The scientific and systematic evaluation of leachates of MSW-affected soils can be a very important approach to establishing a proper management strategy to prevent soil degradation and alleviate the threats posed by the expansion of waste. In this context, the development of the Soil Quality Index (SQI) may be a useful tool to help improve the management of waste soils ${ }^{8,16}$. The term soil quality (SQ) is described as a component of a large ecosystem that supports plant growth and productivity, regulates water flows, maintains environmental quality, and promotes animal and human health ${ }^{6}$. Both qualitative and quantitative soil quality factors can be involved in soil quality assessment. Qualitative SQ assessment has been developed mainly through SQ cards, SQ test kits, and similar items ${ }^{7}$. The current methods of quantitative SQ assessment are soil quality indices (SQI), multiplevariable indicator kriging, the methods based on geographic information system (GIS) data, multivariate geostatic methods, and methods based on a combination of GIS data and fuzzy mathematics ${ }^{8,9}$. Among these methods, SQI has been widely and commonly applied in several works at different scales, locations, and ecosystems, e.g., Biswas et al. ${ }^{10}$ and Li et al. ${ }^{11}$ in Asia, Askari and Holden ${ }^{12}$ and Santos-Francés et al. ${ }^{13}$ in Europe, and Mukherjee and $\mathrm{Lal}^{14}$ and Sione et al. ${ }^{15}$ in America. Simplicity, practicability, and quantitative flexibility are the most important reasons for the common use of the SQI method ${ }^{8}$.

Although, valuable research works have addressed human-induced soil quality degradation in the past few decades, the quantity of SQIs in the croplands affected by uncontrolled leachate has rarely been assessed. Besides, soil heavy metals have been used in the current research to calculate the quality index, while it has not been carried out in previous studies. Heavy metals have been specified as an important factor affecting soil quality and sustainability ${ }^{6}$. These metals are a ubiquitous environmental pollutant which are non-biodegradable, can reduce capable soil resources, and have adverse effects on plant growth and yield ${ }^{2,16}$.

The present study assessed the effects of landfill leachate on SQI in cropland in northwest Iran, where dumping a large amount of MSW generates a huge amount of leachate flowing onto cropland. Understanding and estimating the quality of leachate-impacted soils can establish an opportunity to judge the sustainability of land management and land-use systems ${ }^{16}$. Therefore, the objectives of this study were (a) to compare changes in selected soil attributes between leachate-affected soils and the adjoining unaffected soils and (b) to evaluate the effects of landfill leachate on SQI using the indicator selection methods (total data set and minimum data set) and different SQI models.

\section{Material and methods}

Site characteristics and soil sampling. The study was carried out in an uncontrolled landfill site located approximately $20 \mathrm{~km}$ from Miandoab City in Western Azerbaijan province, north-western Iran (Fig. 1). The site is surrounded by agricultural fields where waste is buried in an uncontrolled open system and without any engineering operations. Wastes on this site are composed of the municipal solid and liquid wastes generated by commercial activities, hospitals, urban municipal, energy generation residues, and industries in Miandoab County. It is estimated that the site has received over 50 tons of waste every day for over 15 years where it is usually burned every week after it reaches a height of 10 to $15 \mathrm{~m}$, resulting in the generation of dark and stinking leachate. The leachate then flows into the cropland around the site as there is no barrier system or leachate collection system in the studied landfill. This has provoked widespread discontent and protests by local farmers and residents of the area. Chemical composition of the investigated leachate is presented in Table S1.

The region has a semi-arid climate with average annual precipitation and temperature of $320 \mathrm{~mm}$ and $13{ }^{\circ} \mathrm{C}$, respectively. The major crop cultivated in the region is rain-fed wheat (Triticum aestivum L.) growing from November to July, i.e. a growth period of about 220 days. Over three decades, conventional cultivation methods have been using tillage and fertilization. Every year, $150-200 \mathrm{~kg} \mathrm{ha}^{-1}$ of urea and $100-150 \mathrm{~kg} \mathrm{ha}^{-1}$ of superphosphate are applied. Superphosphate is soil-incorporated before sowing as a basal treatment, but urea is applied quantitative in two splits, i.e., two-thirds is used as a basal treatment with soil incorporation and the remaining is top-dressed during tillering and stem elongation stages of wheat growth. In the fieldwork, eight soil profilesfour from the leachate-affected soils and four from the control soils-were dug, described, and sampled along a transect at four experimental sites. Due to the similar slope, drainage conditions, parent materials, and soil types, two paired soil profiles (including leachate-affected soil and the adjacent control soil) were specified at each experimental site. A central point was selected for each soil profile, and composite soil samples were taken from four directions including north, south, west, and east of the composite soil samples. Every composite sample was made of three sub-samples. Additionally, the soil sampling process was carried out by a spade from the plow layer (at a depth of $0-0.3 \mathrm{~m}$ ) within a radius of 5-10 m from the central point. All the soil profiles had a high level of calcium carbonate (10-31\%), so the major soil group was Calcisols based on the WRB system ${ }^{17}$. Soil samples were air-dried, grounded, sieved through a 2-mm sieve, and kept in polythene bags for further analysis.

Analysis of soil properties. Soil pH, electrical conductivity (EC), soil organic carbon (SOC), cation exchange capacity (CEC), and calcium carbonate equivalent $\mathrm{CaCO}_{3}$ (CCE) were determined by procedures described by Sparks et al. ${ }^{18}$. Total $\mathrm{N}$ and available $\mathrm{P}$ were estimated using the Kjeldahl approach ${ }^{19}$ and spectrophotometry methods ${ }^{20}$. Soluble and exchangeable cations were measured by the method of saturation extract and $1 \mathrm{~N} \mathrm{NH}_{4} \mathrm{OAc}$, respectively ${ }^{21}$. Sodium absorption ratio (SAR) was computed using the concentration of solution $\mathrm{Na}, \mathrm{Ca}$, and $\mathrm{Mg}$, and exchangeable sodium percentage (ESP) was computed using exchangeable $\mathrm{Na}$ and CEC values ${ }^{22}$.

Available and total fractions of $\mathrm{Zn}, \mathrm{Cu}, \mathrm{Cd}, \mathrm{Pb}$, and $\mathrm{Ni}$ were derived by diethylene-triamine pentaacetic acid (DTPA $)^{23}$ and concentrated nitric acid ${ }^{24}$, respectively. Then, the concentration of the metal was measured by an atomic absorption spectrophotometer (Shimadzu AA-6300). 


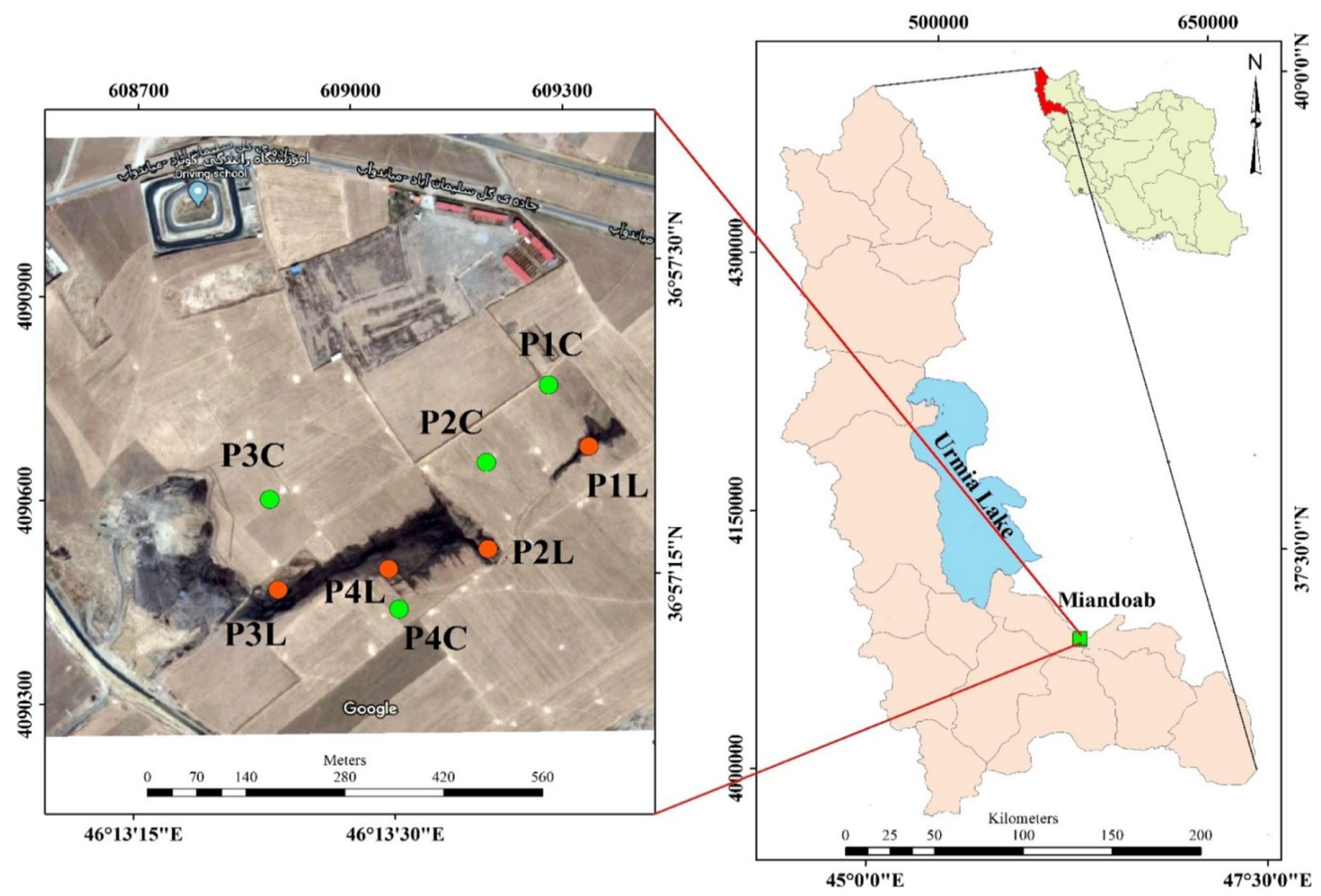

Figure 1. Location of the study area ( $(\mathrm{P} 1 \mathrm{~L}, \ldots$, the soil under influence of leachate; $\mathrm{P} 1 \mathrm{C}, \ldots$ the adjacent control soils) (https://www.qgis.org/ and https://www.google.com/earth/).

Soil quality index (SQI). The study applied both total data set (TDS) and minimum data set (MDS) approaches to assess SQI. A total of 28 soil attributes, i.e. pH, SAR, EC, ESP, CCE, ACC (active calcium carbonate), OM (organic matter), CEC, Total N, Available $\mathrm{P}$, soil ionic composition $\left(\mathrm{Cl}^{-1}, \mathrm{HCO}_{3}^{-1}, \mathrm{Ca}^{2+}, \mathrm{Mg}^{2+}, \mathrm{K}^{+}\right.$, $\mathrm{Na}^{+}$), bioavailable $\mathrm{Fe}$ and $\mathrm{Mn}$, and heavy metals ( $\mathrm{Zn}, \mathrm{Cu}, \mathrm{Cd}, \mathrm{Pb}, \mathrm{Ni}$ ), were identified and considered for the SQI development using TDS. In this regard, all measurable and accessible soil data were indeed used since the TDS approach is capable of producing a comprehensive outcome in evaluating the SQI. In the MDS cause, a principal component analysis (PCA) was carried out on the TDS to reduce the dimensionality of the data and identify the most important variables to be included in the MDS. For each principal component (PC), soil variables with eigenvalue $\geq 1$, which explained at least $5 \%$ of the variance in the data, were selected. The variables with a high absolute loading value obtaining weighted loading amounts within $10 \%$ of the highest weighted factor were considered for the MDS. When more than one variable was presented in any PC, their correlation was analyzed to retain only one in the $\mathrm{MDS}^{8}$. Otherwise, each the indicator with the highest loaded was kept in the MDS.

The data were transformed into dimensionless scores using the standard scoring functions (SSF). Based on the sensitivity of functions in estimating soil quality, three types of SSF involved "the lower, the better", "the upper, the better", and the optimum range. In the study, the "more range" function was used for the soil fertility indices (e.g., OM, CEC, total N, available P, and K); the "low range" function for soil sodicity indices (e.g., SAR, ESP, exchangeable $\mathrm{Na}$ ) and heavy metals; and the "optimum range" function for $\mathrm{pH}$ (the threshold value of 6.5-7.5), EC (the threshold value of $0.2-2 \mathrm{dS} \mathrm{m}^{-1}$ ), and the bioavailable fraction of $\mathrm{Zn}$ (the threshold value of $0.6-10 \mathrm{mg} \mathrm{kg}^{-1}$ ) and $\mathrm{Cu}$ (the threshold value of $\left.0.2-5 \mathrm{mg} \mathrm{kg}^{-1}\right)^{8,10,19,52}$.

The following scoring curves were used as "more or positive range" (Eq. (1)) or "less or negative rage" (Eq. (2)) functions ${ }^{10}$ :

$$
\begin{aligned}
& S L=\frac{X i-X_{\text {min }}}{X_{\text {max }}-X_{\text {min }}} \\
& S L=\frac{X_{\text {max }}-X i}{X_{\text {max }}-X_{\min }}
\end{aligned}
$$

where $S L=$ the linear score, $X i=$ the soil variable content, $X_{\min }=$ the minimum content of soil variable, and $\mathrm{X}_{\max }=$ the maximum content of soil variable. 


\begin{tabular}{|l|l|l|l|l|c|}
\hline \multirow{2}{*}{ SQI senario } & \multicolumn{5}{l|}{ Soil quality grade } \\
\cline { 2 - 6 } & I (very high) & II (high) & III (moderate) & IV (low) & V (very low) \\
\hline IQI-T & $>0.64$ & $0.58-0.64$ & $0.52-0.58$ & $0.46-0.52$ & $<0.46$ \\
\hline NQI-T & $>0.43$ & $0.40-0.43$ & $0.37-0.40$ & $0.34-0.37$ & $<0.34$ \\
\hline IQI-M & $>0.66$ & $0.58-0.62$ & $0.54-0.58$ & $0.51-0.54$ & $<0.51$ \\
\hline NQI-M & $>0.37$ & $0.34-0.37$ & $0.31-0.34$ & $0.28-0.31$ & $<0.28$ \\
\hline
\end{tabular}

Table 1. Categorization of soil quality grades using different methods. IQI: Integrated Quality Index; NQI: Nemoro Quality Index; T: total data set; M: minimum data set.

Further, the SQI was computed using two models including the Integrated Quality Index (IQI) ${ }^{25}$ and Nemoro Quality Index (NQI) ${ }^{26}$ for the TDS and MDS approaches as expressed in Eqs. (3) and (4), respectively:

$$
I Q I=\sum_{i=1}^{n} W_{i} \times S_{i}
$$

where $S_{i}$ is the variable score, $n$ is the number of soil variable, and $\mathrm{W}_{\mathrm{i}}$ is the weighting value of soil variable. The weight values were equal to the ratio of the communality of each variable to the sum communalities of all variables.

$$
\mathrm{NQI}=\sqrt{\frac{\mathrm{P}^{2} \text { ave }+\mathrm{P}^{2} \min }{2}} \times \frac{\mathrm{n}-1}{\mathrm{n}}
$$

where $P^{2}$ ave and $P^{2}$ min are the average and minimum scores of the selected variables, respectively.

In the current study, four different SQIs were assessed using the IQI and NQI methods, the TDS and MDS approaches, and linear scoring methods. Each SQI was divided into five categories involving very high (I), high (II), moderate (III), low (IV), and very low (V) (Table 1$)^{15}$.

To compare and evaluate the accuracy of different SQI models, the sensitivity index and correlation analysis were performed among the SQIs as well as between different SQI methods and wheat grain yield. The sensitivity index was calculated by Eq. (5) as follows ${ }^{27}$.

$$
\mathrm{SI}=\frac{\mathrm{SQI}_{(\max )}}{\mathrm{SQI}_{(\min )}}
$$

where $S Q I_{(\max )}$ and $S Q I_{(\min )}$ are the maximum and minimum of each SQI model, respectively. The higher SI values were assumed to represent more sensitivity potential of the SQI models, impacting both natural and anthropogenic processes ${ }^{27}$.

All statistical analyses (i.e., standard deviations and correlations) were performed by the SPSS 19 software package (SPSS INC., Chicago, USA). The means of different soil variables and different SQI scenarios were compared between the leachage-affected soils and the control soil using a paired t-test.

\section{Results and discussion}

Indices of soil salinity-sodicity and fertility. Table 2 shows the effects of uncontrolled landfill leachate on the selected indices of soil salinity-sodicity and fertility. The $\mathrm{pH}$ of the leachate-affected soils (LAS) was slightly lower (7.3 to 7.5 ) than the control soils (7.5 to 7.8). A significant rise of 78 (site 1 ) to $114 \%$ (site 3 ) occurred in soil EC after the leachate entered the soil probably due to the presence of high levels of cations and anions as well as total dissolved solids in the leachate itself (Table 1). These results are consistent with those reported by Nareen et al. ${ }^{3}$ and Somani et al. $^{28}$. The values of SAR and ESP increased significantly in the LAS compared with the control soil in all soil sites. The leachate inflow into the soil caused a rise of $42-67 \%$ and $35-71 \%$ in SAR and ESP, respectively, which may have aggravated soil quality degradation, particularly the degradation of soil physical properties (e.g. slaking, swelling, and dispersion of clay fraction). The leachate in the soils increased their fertility indices (e.g., OM, CEC, total N, available P, and K) in a range of 15-102\%, implying the positive and improving impact on soil quality. The concentrations of exchangeable cations were in the order of $\mathrm{Ca}>\mathrm{Mg}>\mathrm{Na}>\mathrm{K}$ and $\mathrm{Ca}>\mathrm{Mg}>\mathrm{K}>\mathrm{Na}$ in the LAS and control soils, respectively. The incorporation of leachate into soil produced a slight increase in exchangeable $\mathrm{Ca}$ and $\mathrm{Mg}$, whereas exchangeable $\mathrm{K}$ and $\mathrm{Na}$ were significantly $(\mathrm{P} \leq 0.05)$ enhanced by leachate.

Soil heavy metals. The concentration of bioavailable fraction, extracted by DTPA, of $\mathrm{Zn}, \mathrm{Cu}, \mathrm{Cd}, \mathrm{Pb}$, and $\mathrm{Ni}$ in LAS were estimated to be 15-49, 4-13,0.2-1.1, 2.1-5.2, and 1.3-3.9 $\mathrm{mg} \mathrm{kg}^{-1}$, respectively, while their content was $1.4-7.1,1.5-5.5,0.11-0.44,0.6-2.3$, and $0.4-1.7 \mathrm{mg} \mathrm{kg}^{-1}$ in the control soil, respectively (Table 2). The DTPA-fractions of all heavy metals were significantly higher in LAS than in the control soils. They were in the order of $\mathrm{Zn}>\mathrm{Pb}>\mathrm{Ni}>\mathrm{Cd}>\mathrm{Cu}$. The same trend occurred at all soil sites, reflecting that the process of enriching the DTPA extractable-metals was promoted by leachate in the study area. In this context, $\mathrm{Zn}$ and Cd concentrations were several times higher than those found by other authors ${ }^{29-31}$ in soils similar to the study site (calcareous-semiarid soils). Therefore, soils influenced by leachate may not be advisable for crop production 


\begin{tabular}{|c|c|c|c|c|}
\hline \multirow[b]{2}{*}{ Soil attributes } & \multicolumn{2}{|l|}{ Site 1} & \multicolumn{2}{|l|}{ Site 2} \\
\hline & LAS & Control soil & LAS & Control soil \\
\hline $\mathrm{pH}$ & $7.5 \pm 0.3^{\mathrm{a}}$ & $7.7 \pm 0.1^{\mathrm{a}}$ & $7.4 \pm 0.28^{\mathrm{a}}$ & $7.6 \pm 0.13^{\mathrm{a}}$ \\
\hline $\mathrm{EC}\left(\mathrm{dS} \mathrm{m}^{-1}\right)$ & $3.5 \pm 1.1^{\mathrm{a}}$ & $1.87 \pm 0.4^{\mathrm{b}}$ & $3.79 \pm 1.6^{\mathrm{a}}$ & $1.87 \pm 0.31^{\mathrm{b}}$ \\
\hline SAR & $5.92 \pm 1.1^{\mathrm{a}}$ & $3.84 \pm 0.42^{\mathrm{b}}$ & $4.52 \pm 0.95^{\mathrm{a}}$ & $2.83 \pm 0.4^{\mathrm{b}}$ \\
\hline ESP (\%) & $5.84 \pm 1.2^{\mathrm{a}}$ & $4.01 \pm 0.38^{\mathrm{b}}$ & $7.3 \pm 1.41^{\mathrm{a}}$ & $4.54 \pm 0.92^{\mathrm{b}}$ \\
\hline $\mathrm{OM}\left(\mathrm{g} \mathrm{kg}^{-1}\right)$ & $18.7 \pm 0.6^{\mathrm{a}}$ & $16.2 \pm 0.2^{\mathrm{b}}$ & $21.8 \pm 0.5^{\mathrm{a}}$ & $17.5 \pm 0.3^{\mathrm{b}}$ \\
\hline CEC $\left(\mathrm{cmol} \mathrm{kg}^{-1}\right)$ & $21.9 \pm 3.3^{\mathrm{a}}$ & $18.8 \pm 1.9^{\mathrm{b}}$ & $24.0 \pm 2.8^{\mathrm{a}}$ & $20.1 \pm 1.1^{\mathrm{b}}$ \\
\hline $\operatorname{CCE}\left(\mathrm{g} \mathrm{kg}^{-1}\right)$ & $301 \pm 10.6^{\mathrm{a}}$ & $280 \pm 7.7^{\mathrm{a}}$ & $320 \pm 10.3^{\mathrm{a}}$ & $295 \pm 8.7^{\mathrm{a}}$ \\
\hline Total N (\%) & $0.25 \pm 0.0 .05^{\mathrm{a}}$ & $0.2 \pm 0.01^{\mathrm{b}}$ & $0.33 \pm 0.02^{\mathrm{a}}$ & $0.21 \pm 0.01^{\mathrm{b}}$ \\
\hline Available $\mathrm{P}\left(\mathrm{mg} \mathrm{kg}^{-1}\right)$ & $12.8 \pm 0.4^{\mathrm{a}}$ & $8.86 \pm 0.19^{\mathrm{b}}$ & $11.9 \pm 0.6^{\mathrm{a}}$ & $9.09 \pm 0.27^{b}$ \\
\hline Available $\mathrm{K}\left(\mathrm{mg} \mathrm{kg}^{-1}\right)$ & $440 \pm 25.4^{\mathrm{a}}$ & $337.6 \pm 19.9^{\mathrm{b}}$ & $449.5 \pm 37.5^{\mathrm{a}}$ & $379.7 \pm 30.2^{\mathrm{b}}$ \\
\hline Exchangeable $\mathrm{Ca}\left(\mathrm{cmol}_{\mathrm{c}} \mathrm{kg}^{-1}\right)$ & $15.8 \pm 0.61^{\mathrm{a}}$ & $13.3 \pm 0.52^{\mathrm{b}}$ & $14.9 \pm 0.84^{\mathrm{a}}$ & $13.1 \pm 0.75^{\mathrm{b}}$ \\
\hline Exchangeable $\mathrm{Mg}\left(\mathrm{cmol}_{\mathrm{c}} \mathrm{kg}^{-1}\right)$ & $4.6 \pm 0.32^{\mathrm{a}}$ & $4.0 \pm 0.21^{b}$ & $4.2 \pm 0.28^{\mathrm{a}}$ & $3.7 \pm 0.24^{\mathrm{b}}$ \\
\hline Exchangeable $\mathrm{K}\left(\mathrm{cmol}_{\mathrm{c}} \mathrm{kg}^{-1}\right)$ & $1.23 \pm 0.04^{\mathrm{a}}$ & $0.91 \pm 0.02^{\mathrm{b}}$ & $1.2 \pm 0.0 .8^{\mathrm{a}}$ & $0.90 \pm 0.02^{\mathrm{b}}$ \\
\hline Exchangeable $\mathrm{Na}\left(\mathrm{cmol}_{\mathrm{c}} \mathrm{kg}^{-1}\right)$ & $0.55 \pm 0.06^{\mathrm{a}}$ & $0.36 \pm 0.03^{b}$ & $0.62 \pm 0.34^{\mathrm{a}}$ & $0.38 \pm 0.17^{\mathrm{a}}$ \\
\hline Zn-DTPA $\left(\mathrm{mg} \mathrm{kg}^{-1}\right)$ & $14.5 \pm 2.5^{\mathrm{a}}$ & $2.4 \pm 0.11^{\mathrm{b}}$ & $14.3 \pm 2.7^{\mathrm{a}}$ & $1.2 \pm 0.2^{\mathrm{b}}$ \\
\hline Cu- DTPA (mg kg-1) & $7.2 \pm 1.4^{\mathrm{a}}$ & $1.3 \pm 0.3^{\mathrm{b}}$ & $6.4 \pm 0.6^{\mathrm{a}}$ & $1.3 \pm 0.12^{\mathrm{b}}$ \\
\hline Cd-DTPA $\left(\mathrm{mg} \mathrm{kg}^{-1}\right)$ & $0.65 \pm 0.23^{\mathrm{a}}$ & $0.4 \pm 0.09^{b}$ & $0.59 \pm 0.1^{\mathrm{a}}$ & $0.34 \pm 0.03^{\mathrm{b}}$ \\
\hline Pb DTPA $\left(\mathrm{mg} \mathrm{kg}^{-1}\right)$ & $3.1 \pm 0.36^{\mathrm{a}}$ & $1.1 \pm 0.26^{\mathrm{b}}$ & $3.3 \pm 0.31^{\mathrm{a}}$ & $1.1 \pm 0.21^{\mathrm{b}}$ \\
\hline Ni-DTPA ( $\left.\mathrm{mg} \mathrm{kg}^{-1}\right)$ & $2.2 \pm 0.25^{\mathrm{a}}$ & $0.9 \pm 0.05^{\mathrm{b}}$ & $2.7 \pm 0.2^{\mathrm{a}}$ & $1.4 \pm 0.04^{\mathrm{b}}$ \\
\hline Total Zn $\left(\mathrm{mg} \mathrm{kg}^{-1}\right)$ & $162.9 \pm 8.2^{\mathrm{a}}$ & $63.8 \pm 1.8^{\mathrm{b}}$ & $161.9 \pm 6.3^{\mathrm{a}}$ & $61.3 \pm 1.5^{\mathrm{b}}$ \\
\hline Total $\mathrm{Cu}\left(\mathrm{mg} \mathrm{kg}^{-1}\right)$ & $58.3 \pm 2.1^{\mathrm{a}}$ & $46.2 \pm 1.6^{\mathrm{b}}$ & $55.5 \pm 1.8^{\mathrm{a}}$ & $45.1 \pm 1.3^{\mathrm{b}}$ \\
\hline Total Cd $\left(\mathrm{mg} \mathrm{kg}^{-1}\right)$ & $5.2 \pm 1.2^{\mathrm{a}}$ & $1.8 \pm 0.5^{\mathrm{b}}$ & $5.1 \pm 1.1^{\mathrm{a}}$ & $1.7 \pm 0.3^{\mathrm{b}}$ \\
\hline Total Pb $\left(\mathrm{mg} \mathrm{kg}^{-1}\right)$ & $63.2 \pm 2.3^{\mathrm{a}}$ & $38.9 \pm 0.85^{\mathrm{b}}$ & $77.8 \pm 1.9^{\mathrm{a}}$ & $38.8 \pm 0.71^{\mathrm{b}}$ \\
\hline \multirow[t]{2}{*}{ Total Ni $\left(\mathrm{mg} \mathrm{kg}^{-1}\right)$} & $57.5 \pm 2.5^{\mathrm{a}}$ & $30.5 \pm 0.98^{\mathrm{b}}$ & $59.1 \pm 1.7^{\mathrm{a}}$ & $31.2 \pm 0.76^{\mathrm{b}}$ \\
\hline & \multicolumn{2}{|l|}{ Site 3} & \multicolumn{2}{|l|}{ Site 4} \\
\hline Soil attributes & LAS & Control soil & LAS & Control soil \\
\hline $\mathrm{pH}$ & $7.3 \pm 0.14^{\mathrm{a}}$ & $7.5 \pm 0.1^{\mathrm{a}}$ & $7.5 \pm 0.2^{\mathrm{a}}$ & $7.8 \pm 0.14^{\mathrm{a}}$ \\
\hline $\mathrm{EC}\left(\mathrm{dS} \mathrm{m}^{-1}\right)$ & $5.98 \pm 2.1^{\mathrm{a}}$ & $2.8 \pm 0.8^{\mathrm{b}}$ & $3.4 \pm 1.2^{\mathrm{a}}$ & $1.65 \pm 0.5^{\mathrm{b}}$ \\
\hline SAR & $5.94 \pm 0.91^{\mathrm{a}}$ & $3.91 \pm 0.53^{\mathrm{b}}$ & $6.6 \pm 0.98^{\mathrm{a}}$ & $3.95 \pm 0.44^{\mathrm{b}}$ \\
\hline ESP(\%) & $4.84 \pm 1.03^{\mathrm{a}}$ & $3.03 \pm 0.31^{\mathrm{b}}$ & $6.65 \pm 0.81^{\mathrm{a}}$ & $3.9 \pm 0.3^{\mathrm{b}}$ \\
\hline $\mathrm{OM}\left(\mathrm{g} \mathrm{kg}^{-1}\right)$ & $19.0 \pm 0.3^{\mathrm{a}}$ & $15.7 \pm 0.2^{\mathrm{b}}$ & $22.7 \pm 0.43^{\mathrm{a}}$ & $18.5 \pm 0.24^{\mathrm{b}}$ \\
\hline $\operatorname{CEC}\left(\mathrm{cmol} \mathrm{kg}^{-1}\right)$ & $18.4 \pm 2.8^{\mathrm{a}}$ & $15.6 \pm 1.1^{\mathrm{b}}$ & $24.6 \pm 3.4^{\mathrm{a}}$ & $20.63 \pm 2.1^{b}$ \\
\hline CCE $\left(\mathrm{g} \mathrm{kg}^{-1}\right)$ & $282 \pm 10.3^{\mathrm{a}}$ & $263 \pm 8.7^{b}$ & $310 \pm 8.3^{\mathrm{a}}$ & $291 \pm 7.6^{\mathrm{a}}$ \\
\hline Total N (\%) & $0.21 \pm 0.02^{\mathrm{a}}$ & $0.15 \pm 0.01^{\mathrm{b}}$ & $0.23 \pm 0.03^{\mathrm{a}}$ & $0.18 \pm 0.01^{\mathrm{b}}$ \\
\hline Available $\mathrm{P}\left(\mathrm{mg} \mathrm{kg}^{-1}\right)$ & $10.45 \pm 0.67^{\mathrm{a}}$ & $8.19 \pm 0.27^{\mathrm{b}}$ & $12.17 \pm 0.54^{\mathrm{a}}$ & $10.21 \pm 0.34^{\mathrm{b}}$ \\
\hline Available $\mathrm{K}\left(\mathrm{mg} \mathrm{kg}^{-1}\right)$ & $420 \pm 37.5^{\mathrm{a}}$ & $340 \pm 30.3^{\mathrm{b}}$ & $417 \pm 29.8^{\mathrm{a}}$ & $342 \pm 25.7^{b}$ \\
\hline Exchangeable $\mathrm{Ca}\left(\mathrm{cmol}_{\mathrm{c}} \mathrm{kg}^{-1}\right)$ & $13.4 \pm 0.84^{\mathrm{a}}$ & $11.9 \pm 0.73^{\mathrm{b}}$ & $15.5 \pm 0.61^{\mathrm{a}}$ & $14.0 \pm 0.54^{\mathrm{a}}$ \\
\hline Exchangeable $\mathrm{Mg}\left(\mathrm{cmol}_{\mathrm{c}} \mathrm{kg}^{-1}\right)$ & $3.7 \pm 0.2^{\mathrm{a}}$ & $3.3 \pm 0.1^{\mathrm{a}}$ & $4.3 \pm 0.3^{\mathrm{a}}$ & $3.9 \pm 0.2^{\mathrm{a}}$ \\
\hline Exchangeable $\mathrm{K}\left(\mathrm{cmol}_{\mathrm{c}} \mathrm{kg}^{-1}\right)$ & $1.01 \pm 0.06^{\mathrm{a}}$ & $0.86 \pm 0.04^{\mathrm{b}}$ & $1.2 \pm 0.11^{\mathrm{a}}$ & $0.97 \pm 0.03^{\mathrm{b}}$ \\
\hline Exchangeable $\mathrm{Na}\left(\mathrm{cmol}_{\mathrm{c}} \mathrm{kg}^{-1}\right)$ & $0.68 \pm 0.2^{\mathrm{a}}$ & $0.38 \pm 0.1^{\mathrm{b}}$ & $0.49 \pm 0.09^{\mathrm{a}}$ & $0.26 \pm 0.08^{\mathrm{b}}$ \\
\hline Zn-DTPA $\left(\mathrm{mg} \mathrm{kg}^{-1}\right)$ & $17.8 \pm 1.2^{\mathrm{a}}$ & $1.5 \pm 0.21^{\mathrm{b}}$ & $23.8 \pm 1.4^{\mathrm{a}}$ & $0.9 \pm 0.1^{\mathrm{b}}$ \\
\hline $\mathrm{Cu}-$ DTPA $\left(\mathrm{mg} \mathrm{kg}^{-1}\right)$ & $5.3 \pm 0.78^{\mathrm{a}}$ & $1.2 \pm 0.2^{\mathrm{b}}$ & $6.7 \pm 0.57^{\mathrm{a}}$ & $1.1 \pm 0.1^{\mathrm{b}}$ \\
\hline Cd-DTPA $\left(\mathrm{mg} \mathrm{kg}^{-1}\right)$ & $0.54 \pm 0.05^{\mathrm{a}}$ & $0.3 \pm 0.02^{\mathrm{b}}$ & $0.53 \pm 0.04^{\mathrm{a}}$ & $0.26 \pm 0.02^{\mathrm{b}}$ \\
\hline Pb DTPA $\left(\mathrm{mg} \mathrm{kg}^{-1}\right)$ & $3.7 \pm 0.2^{\mathrm{a}}$ & $1.3 \pm 0.1^{\mathrm{b}}$ & $3.3 \pm 0.26^{\mathrm{a}}$ & $1.2 \pm 0.15^{\mathrm{b}}$ \\
\hline Ni-DTPA $\left(\mathrm{mg} \mathrm{kg}^{-1}\right)$ & $2.3 \pm 0.3^{\mathrm{a}}$ & $0.98 \pm 0.03^{\mathrm{b}}$ & $2.9 \pm 0.25^{\mathrm{a}}$ & $1.1 \pm 0.02^{\mathrm{b}}$ \\
\hline Total Zn $\left(\mathrm{mg} \mathrm{kg}^{-1}\right)$ & $166.1 \pm 6.8^{\mathrm{a}}$ & $63.3 \pm 1.5^{\mathrm{b}}$ & $164.3 \pm 4.2^{\mathrm{a}}$ & $62.6 \pm 1.1^{\mathrm{b}}$ \\
\hline Total $\mathrm{Cu}\left(\mathrm{mg} \mathrm{kg}^{-1}\right)$ & $55.7 \pm 1.8^{\mathrm{a}}$ & $45.1 \pm 1.3^{\mathrm{b}}$ & $55.6 \pm 1.4^{\mathrm{a}}$ & $45.2 \pm 0.98^{\mathrm{b}}$ \\
\hline Total Cd $\left(\mathrm{mg} \mathrm{kg}^{-1}\right)$ & $5.3 \pm 0.97^{\mathrm{a}}$ & $1.9 \pm 0.3^{\mathrm{b}}$ & $5.2 \pm 1.3^{\mathrm{a}}$ & $1.8 \pm 0.25^{\mathrm{b}}$ \\
\hline Total Pb $\left(\mathrm{mg} \mathrm{kg}^{-1}\right)$ & $80.4 \pm 2.5^{\mathrm{a}}$ & $46.4 \pm 1.2^{\mathrm{b}}$ & $66.1 \pm 2.1^{\mathrm{a}}$ & $33.6 \pm 0.94^{\mathrm{b}}$ \\
\hline Total $\mathrm{Ni}\left(\mathrm{mg} \mathrm{kg}^{-1}\right)$ & $61.3 \pm 3.2^{\mathrm{a}}$ & $30.8 \pm 1.1^{\mathrm{b}}$ & $56.4 \pm 1.9^{\mathrm{a}}$ & $30.7 \pm 0.97^{\mathrm{b}}$ \\
\hline
\end{tabular}

Table 2. Comparison of soil variables values (mean \pm SD) between LAS and adjacent control soil $(n=60)$. SD: standard deviation; LAS: leachate-affected soil; OM: organic matter; CCE: calcium carbonate equivalent; CEC: cation exchange capacity; EC: electrical conductivity; SAR: sodium adsorption ratio; ESP: exchangeable sodium percentage. Different letters in each row show significant differences at $\mathrm{P}<0.05$ based on the paired t-test. 


\begin{tabular}{|c|c|c|c|c|}
\hline & \multicolumn{2}{|l|}{ TDS methods } & \multicolumn{2}{|c|}{ MDS methods } \\
\hline & Commnuity & Weight & Commnuity & Weight \\
\hline $\mathrm{pH}$ & 0.638 & 0.026 & & \\
\hline $\mathrm{EC}\left(\mathrm{dS} \mathrm{m} \mathrm{m}^{-1}\right)$ & 0.998 & 0.042 & 0.943 & 0.208 \\
\hline SAR & 0.992 & 0.041 & 0.934 & 0.204 \\
\hline $\mathrm{ESP}(\%)$ & 0.990 & 0.040 & & \\
\hline $\mathrm{OM}\left(\mathrm{g} \mathrm{kg}^{-1}\right)$ & 0.979 & 0.040 & 0.916 & 0.20 \\
\hline CEC $\left(\mathrm{cmol} \mathrm{kg}^{-1}\right)$ & 0.939 & 0.038 & & \\
\hline $\mathrm{CCE}\left(\mathrm{g} \mathrm{kg}^{-1}\right)$ & 0.738 & 0.030 & & \\
\hline Total N (\%) & 0.948 & 0.039 & & \\
\hline Available P $\left(\mathrm{mg} \mathrm{kg}^{-1}\right)$ & 0.781 & 0.032 & & \\
\hline Available $\mathrm{K}\left(\mathrm{mg} \mathrm{kg}^{-1}\right)$ & 0.726 & 0.030 & & \\
\hline Exchangeable $\mathrm{Ca}\left(\mathrm{cmol}_{\mathrm{c}} \mathrm{kg}^{-1}\right)$ & 0.845 & 0.034 & 0.829 & 0.181 \\
\hline Exchangeable $\mathrm{Mg}\left(\mathrm{cmol}_{\mathrm{c}} \mathrm{kg}^{-1}\right)$ & 0.858 & 0.035 & & \\
\hline Exchangeable $\mathrm{K}\left(\mathrm{cmol}_{\mathrm{c}} \mathrm{kg}^{-1}\right)$ & 0.924 & 0.038 & & \\
\hline Exchangeable $\mathrm{Na}\left(\mathrm{cmol}_{\mathrm{c}} \mathrm{kg}^{-1}\right)$ & 0.922 & 0.038 & & \\
\hline Soluble Ca $\left(\mathrm{meq} \mathrm{l}^{-1}\right)$ & 0.870 & 0.036 & & \\
\hline Soluble $\mathrm{Mg}\left(\mathrm{meq}^{-1}\right)$ & 0.938 & 0.039 & & \\
\hline Soluble K (meq l-1) & 0.893 & 0.035 & & \\
\hline Soluble Na $\left(\mathrm{meq}^{-1}\right)$ & 0.908 & 0.037 & & \\
\hline Zn-DTPA (mg kg-1) & 0.993 & 0.041 & & \\
\hline Cu- DTPA (mg kg $\left.{ }^{-1}\right)$ & 0.979 & 0.040 & & \\
\hline Cd-DTPA (mg kg $\left.{ }^{-1}\right)$ & 0.948 & 0.041 & & \\
\hline Pb DTPA $\left(\mathrm{mg} \mathrm{kg}^{-1}\right)$ & 0.939 & 0.039 & & \\
\hline Ni-DTPA (mg kg-1) & 0.931 & 0.038 & & \\
\hline Total Zn $\left(\mathrm{mg} \mathrm{kg}^{-1}\right)$ & 0.935 & 0.040 & 0.957 & 0.209 \\
\hline Total $\mathrm{Cu}\left(\mathrm{mg} \mathrm{kg}^{-1}\right)$ & 0.947 & 0.039 & & \\
\hline Total Cd $\left(\mathrm{mg} \mathrm{kg}^{-1}\right)$ & 0.778 & 0.032 & & \\
\hline Total Pb $\left(\mathrm{mg} \mathrm{kg}^{-1}\right)$ & 0.968 & 0.040 & & \\
\hline Total Ni $\left(\mathrm{mg} \mathrm{kg}^{-1}\right)$ & 0.935 & 0.038 & & \\
\hline
\end{tabular}

Table 3. The communality and weight values of each soil variable for both TDS and MDS approach. TDS: total data set; MDS: minimum data set; OM: organic matter; CCE: calcium carbonate equivalent; CEC: cation exchange capacity; EC: electrical conductivity; SAR: sodium adsorption ratio; ESP: exchangeable sodium percentage.

given DTPA-Zn and Cd as reported in previous works ${ }^{3,32}$. Safety and phytotoxic problems caused by the available fraction of these two elements have also been reported in previous works. The possible reason for the increase in $\mathrm{Zn}$ and $\mathrm{Cd}$ may be the high amount of residual vehicle tires, batteries, colored materials, and colored glass and inks on paper that are commonly found in the waste ${ }^{6,33}$. Similar to available fraction, the total fraction of five heavy metals was significantly conditioned by leachate. Enriched values of metals were found to be in the order of $\mathrm{Cd}(180-200 \%)>\mathrm{Zn}(155-164 \%)>\mathrm{Ni}(84-99 \%)>\mathrm{Pb}(62-100 \%)>\mathrm{Cu}(23-32 \%)$. However, the mean values of the metals were lower than their acceptable ranges except for $\mathrm{Cd}$. This implies that the total Cd contamination (as with its available fraction) occurred when leachate entered the soil. Soil pollution by Cd-induced leachate has also been found in other works, e.g., Liu et al. ${ }^{34}$ from China and Adamcová et al. ${ }^{35}$ from the Czech Republic. The values of heavy metals and other soil variables varied depending on the soil site, which might have contributed to the properties of the leachate itself (e.g., the quantity and quality of the leachate) and the impact of the leachate on the affected soils.

Soil Quality Indices (SQI). The TDS approach. Given twenty-eight soil variables, the SQI was calculated using the TDS approach and two IQI and NQI models (IQI-T and NQI-T). Considering the communality analysis (Table 3), the indices of soil salinity-sodicity (e.g., EC, SAR, and ESP) and soil heavy metal (e.g. Zn, Cu, and $\mathrm{Cd}$ ) had the highest weight (ranging from 0.04 to 0.042 ), suggesting that these variables can have a remarkable impact on the IQI-T and NQI-T. The importance of these variables on TDS can be attributed to their role in multiple soil functions and processes that are important from the soil quality degradation aspect ${ }^{36}$. In the LAS, a range from 0.44 to 0.6 with a mean value of 0.47 and from 0.34 to 0.39 with a mean value of 0.36 were recorded for the IQI-T and NQI-T, respectively.

The IQI-T and NQI-T were found in a range of 0.53 to 0.78 with a mean value of 0.62 and from 0.37 to 0.41 with a mean value of 0.39 in the control soils, respectively. The soil quality was grade III and grade IV in most soil sites affected by leachate and the control soils, respectively, regarding both IQI-T $(0.52>$ SQI $\geq 0.46)$ and NQI-T $(0.37>$ SQI $\geq 0.34$ ) (Table 1$)$. A considerable area of the grade III-IV soil quality has been reported in 

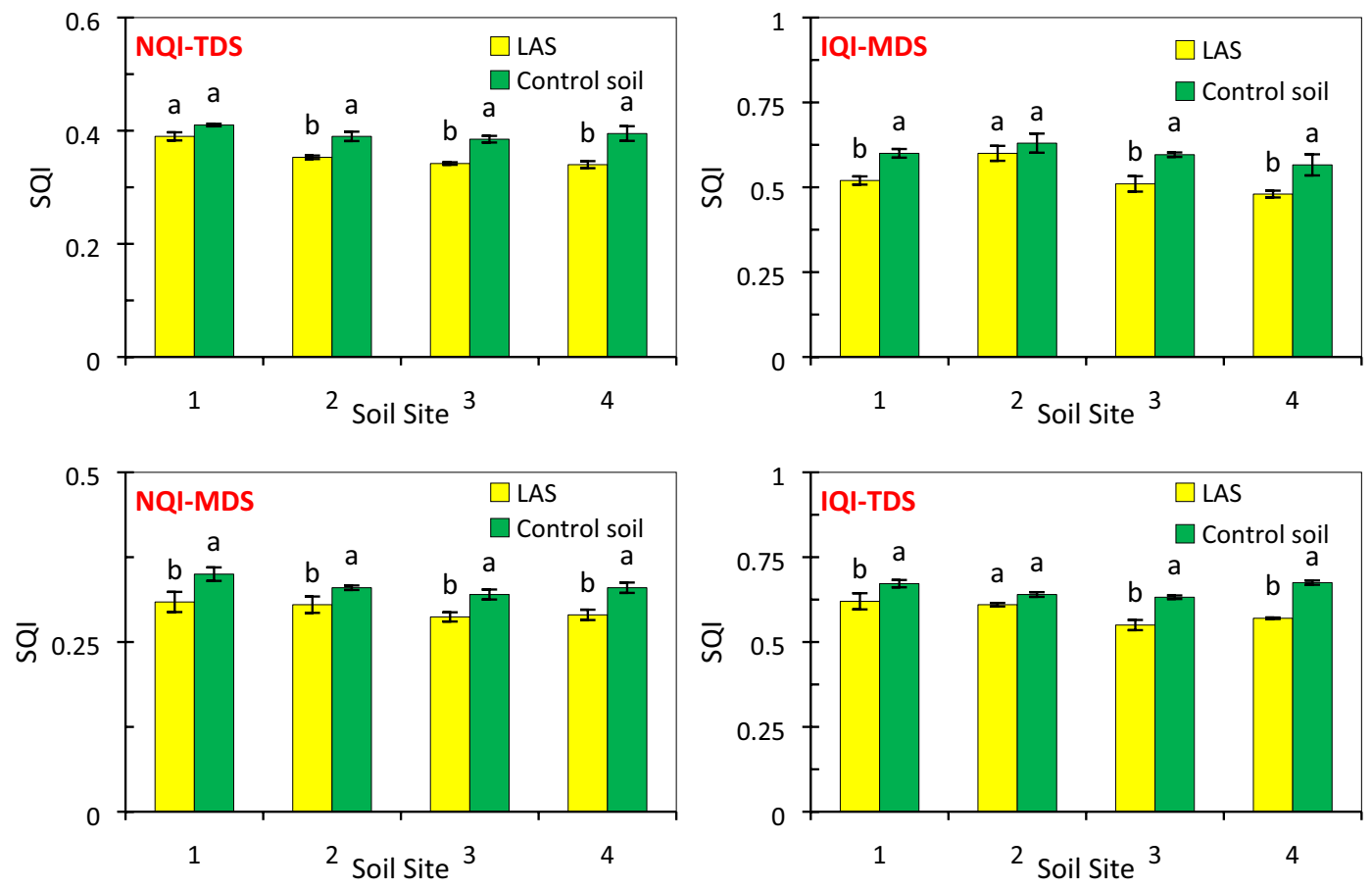

Figure 2. The comparison of the mean values of different soil quality index (SQI) scenarios between the leachate-affected soil (LAS) and the control soils.

other studies in semi-arid regions ${ }^{37-39}$. Grade III has been identified as moderately suitable for plant growth but with some limitations while grade IV has more severe limitations for plant growth ${ }^{26}$. The IQT-T and NQI-T values dropped in the LAS, ranging from 5 to $16 \%$ and 6.5 to $13 \%$, respectively, as compared to the control soils (Fig. 2) showing that the leachate has a negative and degradative effect on soil quality. The results corroborate the findings of other studies who found that municipal solid waste and landfill leachate cause the degradation of general soil quality by soil salinity and heavy metals ${ }^{40-42}$. The highest drop of IQT-T and NQI-T values were observed in site 4 where the highest rise occurred in the values of EC, SAR, and ESP for the LAS than those in the control. These variables contain the most important factors degrading soil quality in semi-arid environments (just like the current study), resulting in a greater decrease in SQI in site 4 than in the other sites. Soil salinity and sodicity indices (e.g., EC, SAR, and ESP) are also consistent with most indicators commonly used for soil quality assessment in arid and semi-arid areas ${ }^{16,38,43}$.

The MDS approach. As more research studies focused on quantifying SQI, it has become clear that its calculation is very costly and time-consuming if all soil attributes are used. Therefore, soil science researchers are trying to introduce methods that require fewer data while having good accuracy, which will, in turn, reduce the cost and time of SQI estimation. One of the most important alternatives is the minimum data set (MDS) method using principal component analysis, which is accepted by researchers and is widely applied ${ }^{14,16,44}$.

Here, a principal component analysis (PCA) was used to determine the MDS based on the standardized data matrix of the TDS (Table 4). Three PCs were specified to have eigenvalues $>1$ ranging from 2.12 to 19.98, which accounted for $89.01 \%$ of the total variance in the original data. PC1, capturing $71.36 \%$ of the variance in data, had seven variables including EC, OM, available $\mathrm{P}$, soluble $\mathrm{K}$ and $\mathrm{Mg}$, and total $\mathrm{Zn}$ and $\mathrm{Cu}$. There was a significant correlation $(\mathrm{P}<0.01)$ between $\mathrm{EC}$ and soluble $\mathrm{K}$ and $\mathrm{Mg}$, between $\mathrm{OM}$ and available $\mathrm{P}$, and between total $\mathrm{Zn}$ and $\mathrm{Cu}$. In the PC, EC, OM, and total $\mathrm{Zn}$ were retained in the MDS due to their higher-loading value. Referring to literature ${ }^{8,12,16}$, when the correlated variables in a PC are important factors affecting soil quality, those that include MDS are more important and the value of loading is higher. PC2 captured $10.06 \%$ of the total variance, and it was mostly loaded by SAR (0.959), ESP (0.911), exchangeable K (0.94), and Na (0.87), which were correlated with each other, and SAR was selected for the MDS. Under PC3, accounting for $7.58 \%$ of the total variance, exchangeable $\mathrm{Ca}$ and $\mathrm{Mg}$ were dominated with a loading value of 0.848 and 0.836 , respectively.

These two variables were significantly correlated with each other $(\mathrm{P}<0.05)$ and exchangeable $\mathrm{Ca}$ (with more load value) was involved in the MDS. Consequently, five soil variables including EC, OM, total Zn, SAR, and exchangeable Ca were contained in the MDS in the present work. These findings followed the data of Andrews et al. ${ }^{8}$ and Karlen et al. ${ }^{45}$, who suggested that the quantitative soil quality assessment can be performed using at least five soil variables. The number of soil variables diminished from twenty-eight associated with the TDS to five in the MDS, showing a drop of more than $80 \%$ in soil variables using the MDS approach. This can significantly save money and improve work output. Besides, the soil variables included in the MDS of the study (mainly EC, OM, and ESP) are widely employed in the development of SQI by other researches, e.g., Nabiollahi et al. ${ }^{38}$ and 


\begin{tabular}{|c|c|c|c|}
\hline PCs & PC1 & PC2 & PC3 \\
\hline Eigen value & 19.98 & 2.82 & 2.12 \\
\hline Variance (\%) & 71.36 & 10.06 & 7.58 \\
\hline Cumulative variance (\%) Eigenvectors & 71.36 & 81.42 & 89.01 \\
\hline $\mathrm{pH}$ & -0.730 & -0.274 & 0.174 \\
\hline EC & $\underline{0.968}$ & 0.573 & 0.097 \\
\hline SAR & -0.460 & $\underline{0.959}$ & -0.261 \\
\hline ESP & 0.206 & $\underline{0.911}$ & 0.011 \\
\hline $\mathrm{OM}$ & $\underline{0.936}$ & 0.577 & 0.234 \\
\hline CEC & -0.672 & 0.503 & 0.477 \\
\hline CCE & 0.777 & 0.239 & -0.298 \\
\hline Total N & -0.768 & 0.514 & 0.308 \\
\hline Available P & $\underline{0.812}$ & 0.238 & 0.253 \\
\hline Available K & 0.273 & 0.55 & -0.591 \\
\hline Exchangeable Ca & -0.070 & 0.259 & $\underline{0.848}$ \\
\hline Exchangeable Mg & 0.351 & -0.192 & $\underline{0.836}$ \\
\hline Exchangeable K & 0.200 & $\underline{0.940}$ & -0.034 \\
\hline Exchangeable $\mathrm{Na}$ & 0.371 & $\underline{0.870}$ & 0.162 \\
\hline Soluble Ca & 0.745 & 0.468 & 0.311 \\
\hline Soluble Mg & $\underline{0.834}$ & 0.472 & 0.135 \\
\hline Soluble K & $\underline{0.901}$ & -0.276 & -0.071 \\
\hline Soluble Na & 0.695 & 0.651 & -0.034 \\
\hline Zn-DTPA & 0.734 & 0.639 & 0.073 \\
\hline Cu-DTPA & 0.727 & 0.591 & 0.263 \\
\hline Cd-DTPA & 0.791 & 0.351 & 0.172 \\
\hline Pb-DTPA & 0.759 & 0.622 & 0.07 \\
\hline Ni-DTPA & 0.637 & 0.734 & 0.094 \\
\hline Total Zn & $\underline{0.979}$ & 0.587 & 0.072 \\
\hline Total $\mathrm{Cu}$ & $\underline{0.813}$ & 0.548 & 0.135 \\
\hline Total Cd & 0.775 & 0.586 & 0.06 \\
\hline Total Pb & 0.759 & 0.576 & -0.193 \\
\hline Total Ni & 0.799 & 0.525 & -0.128 \\
\hline
\end{tabular}

Table 4. Data of principal component analysis (PCA) for soil quality variables. TDS: total data set; MDS: minimum data set; OM: organic matter; CCE: calcium carbonate equivalent; CEC: cation exchange capacity; EC: electrical conductivity; SAR: sodium adsorption ratio; ESP: exchangeable sodium percentage. Underlined bold font values are considered highly weighted.

Jahany and Rezapour ${ }^{16}$. This may be explained by the crucial effects of the variables on multiple soil functions including the combination of soil physical attributes, soil productivity, crop yield, and microbial community ${ }^{6}$. Data were found by De Clerck et al. ${ }^{46}$ suggesting that some soil variables (e.g. EC and organic matter) are most sensitive to management options and the most desirable of indicator to contribution into SQI. The equation for the integrated SQI using MDS (IQI-MDS) is given below:

$$
I Q I-M D S=0.209 \mathrm{Zn}+0.208 E C+0.204 S A R+0.20 O M+0.181 C a
$$

After leachate entered the soil, a range of $0.48-0.6$ with a mean value of 0.53 and a range of $0.28-0.31$ with a mean value of 0.30 was observed for the IQI-M and NQI-M, respectively. These indices (IQI-M and NQI-M) were recorded in a range of 0.56 to 0.63 with a mean value of 0.60 and $0.32-0.35$ with a mean value of 0.33 in the control soils, respectively. Using the SQI grades of the MDS approach (Table 1), there were grades III and IV based on IQI $(0.54>$ SQI $\geq 0.58)$ and NQI $(0.28>$ SQI $\geq 0.31)$, respectively, in the majority of soil sites impacted by leachate which is almost similar to those determined for the TDS approach. On the other hand, the grades II and III soils were determined in the control sites using IQI-M and NQI-M, respectively, depicting that the grade of soil quality has dropped after adding the leachate to the soils, similar to what was occurred with the TDS approach. The SQI-MDS values ranged from 0.48 to 0.6 with a mean value of 0.53 for the IQI model and from 0.56 to 0.63 with a mean value of 0.6 for its control soil. For the NQI model, the values were in the range of $0.28-0.31$ with a mean value of 0.3 and $0.32-0.35$ with a mean value of 0.33 for its control soil. As with the TDS method, a drop of 5-15.2\% and 7.5-12.2\% was occurred in SQI using the IQI and NQI models (Fig. 2), implying that soil quality degradation was increased and stimulated by the leachate. The findings are in accordance with the results of previous studies that found that waste leachate can promote soil degradation by soil salinization and leaving organic and metal pollutants ${ }^{47}$. 

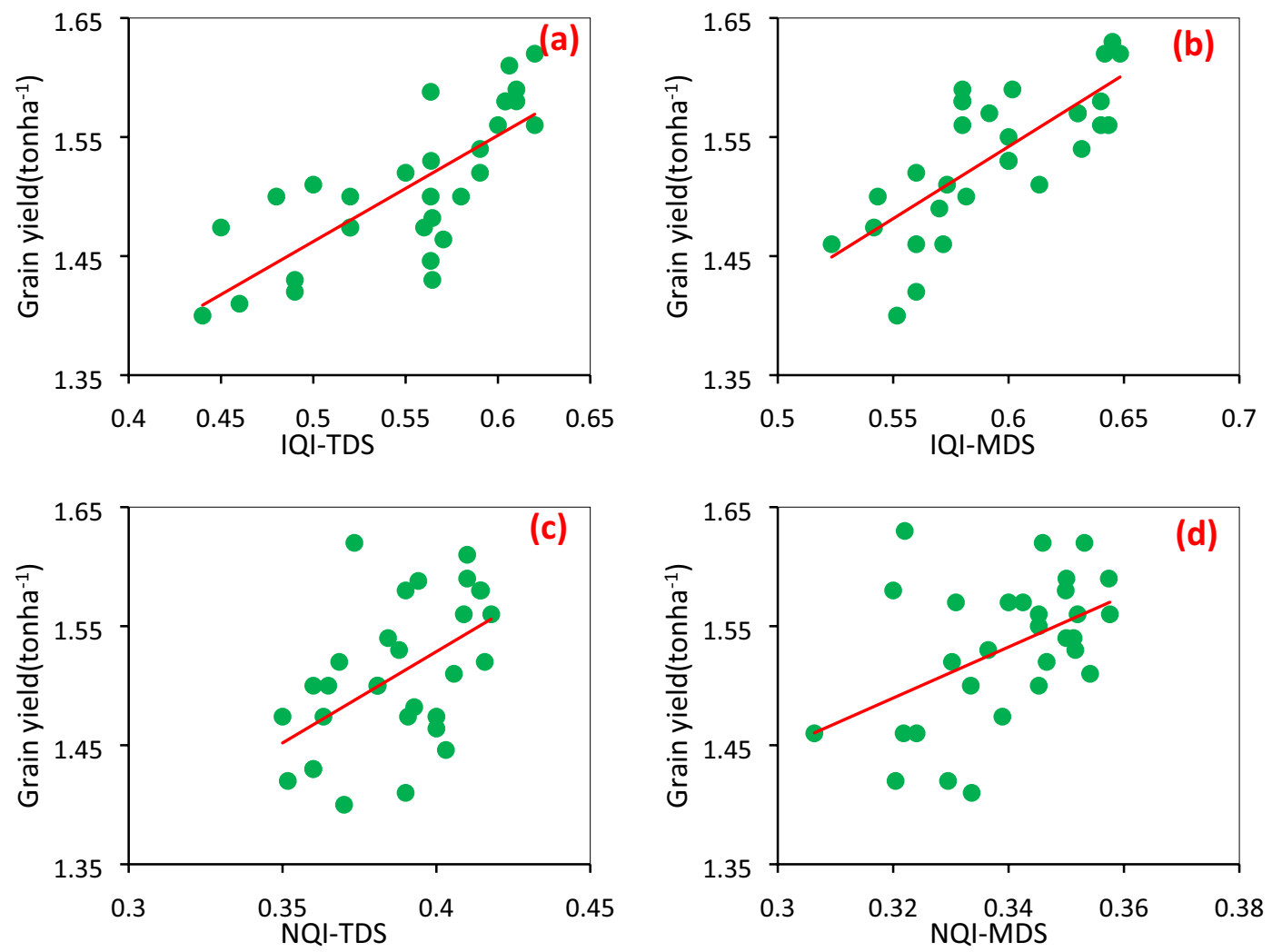

Figure 3. Wheat grain yield versus IQI-TDS (a), IQI-MDS (b), NQI-TDS (c), and NQI-MDS (d).

Among the four soil sites, site 4 had the highest drop in both IQI-MDS and NQI-MDS followed by site 3, an almost similar tendency to the SQI-TDS approach. This may have resulted from the higher rate of the rise in EC and SAR after the leak of the leachate into the soil of sites 3 and 4 than the other sites. Given the weight of each variable (Table 3 ), the two variables are including the most powerful variables affecting MDS approach, resulting in more drop of SQI in some sites (e.g., sites 3 and 4) than other sites.EC and SAR have been widely used to describe SQI and have been specified to be very sensitive to agricultural management processes mainly in arid and semi-arid regions ${ }^{6}$. The degradative effects of EC and SAR may be linked to their negative impact on a combination of physicochemical and biological indicators of soil (e.g., soil structure, soil permeability and infiltration of water and air, soil osmotic pressure, soil fertility and nutrient cycling, and soil microbial community), thereby reducing plant growth, production, and vegetation covers ${ }^{48}$. The increasing pattern of EC and SAR in the LAS may be associated with the chemistry of waste leachate (Table S1) which is rich in the soluble salts (e.g., $\mathrm{Ca}^{2+}, \mathrm{Na}^{+}, \mathrm{Cl}^{-}$, and $\mathrm{HCO}_{3}^{-}$), resulting in a significant increase in $\mathrm{EC}$ of the soils receiving leachate. On the other hand, the high content of $\mathrm{Na}^{+}$and $\mathrm{HCO}_{3}{ }^{-}$generated by leachate linked to the evapotranspiration process may lead to the depletion of $\mathrm{Ca}^{2+}$ and $\mathrm{Mg}^{2+}$ ions as insoluble carbonates (e.g., calcite and magnesite) whereas soluble $\mathrm{Na}$ is more concentrated in the solution and subsequently, it increases the SAR values in the LAS ${ }^{16,48}$.

Relationship between SQI and wheat yield. All SQI models (IQI-T, NQI-T, IQI-M, and NQI-M) had a significant relationship with the wheat yield based on the regression equations (Fig. 3), showing that the variations in the wheat yield could be captured by any of the models. The contributions of the wheat yield to SQI may be associated with the choice of soil variables (e.g., organic matter, macronutrients, and micronutrients), which may directly relate to crop performance. Several authors have suggested that crop yields are invariably associated with soil fertility indices and hence SQI may result in a high correlation with yields when some of the related attributes are involved in the SQI ${ }^{14,49}$. Our results are in line with several works from other regions, e.g., Vasu et $a l .{ }^{50}$ from India, de Paul Obade and $\mathrm{Lal}^{51}$ from the US, and Li et al. ${ }^{11}$ from China who found the $\mathrm{R}^{2}$ of SQI versus crop yields in a range of $0.4-0.89$.

The regression coefficients of IQI-T with the wheat yield was the highest, followed by IQI-M and NQI-T and NQI-M, implying that the IQI-T methods presented a better indication of variability in the wheat yield than the other methods. However, our suggestion to use the SQI-M for predicting wheat yield that its $\mathrm{R}^{2}$ has a narrow different with $\mathrm{R}^{2}$ of the IQI-T method because the TDS requires multiple numbers of soil indicators, increasing the time and cost of assessing soil quality. Moreover, in both LAS and controls soil, the mean value of sensitivity index (SI) was diminished in the order of IQI-M (1.35)> IQI-T (1.21)> NQI-M (1.15) > NQI-T (1.1), supporting more sensibility of the IQI-M model than the other models in assessing soil quality and wheat yield. Some researchers, including Mukhopadhyay et al..$^{52}$, Raiesi ${ }^{53}$, and Karkaj et al..$^{54}$, have compared different models of 


\begin{tabular}{|l|l|l|l|l|}
\hline & IQI-T & IQI-M & NQI-T & NQI-M \\
\hline IQI-T & 1.00 & $0.88^{* *}$ & $0.71^{* *}$ & $0.81^{* *}$ \\
\hline IQI-M & $0.88^{* *}$ & 1.00 & $0.74^{* *}$ & $0.74^{* *}$ \\
\hline NQI-T & $0.71^{* *}$ & $0.81^{* *}$ & 1.00 & $0.71^{\star}$ \\
\hline NQI-M & $0.81^{* *}$ & $0.74^{* *}$ & $0.71^{\star}$ & 1.00 \\
\hline
\end{tabular}

Table 5. Correlation matrix for the eight SQI. ${ }^{*}$ Correlation is significant at the 0.01 level. ${ }^{*}$ Correlation is significant at the 0.05 level.

SQI evaluation by sensitivity index and found that the SI is an effective tool to assess the differentiating ability among different SQL scenarios. Using both TDS and MDS approaches, the regression coefficients of the IQI model were higher than those of the NQI model, reflecting that the IQI model provides a more accurate assessment of crop yield than the NQI model. This may be attributed to the fact that the combination of scoring and weighting is considered for soil variables in the IQI method whereas the NQI model is calculated only based on the average values and the minimum score of the characteristics ${ }^{55}$. Comparing different methods of determining SQI by Mukherjee and Lal ${ }^{14}$ showed that the IQI method had a stronger correlation with crop yield than the other methods due to the appropriate weight allocation for soil characteristics.

Comparison of SOI models. All SQI models were significantly and positively correlated with one another with correlation coefficients ranging from 0.71 to 0.86 (Table 5), suggesting that either of the models could have been used to monitor soil quality in the present study. Nevertheless, the differentiating ability of SQI based on the IQI method was not the same as the SQI based on the NQI method.

In this respect, the correlation coefficients and SI (as discussed before) for IQI were always higher those for NQI had higher values. Comparing the different scenarios of SQI assessment, several researchers ${ }^{38,44,55,56}$ have found that the IQI method outperforms the NQI method in the assessment of soil quality.

Among the four models used in the present study, the IQI determined based on MDS was found to be the optimal model to estimate soil quality and predict crop yields given the analysis of the correlations among the SQI models, the correlations between the SQI models and wheat yield, and sensitivity index values.

\section{Conclusions}

The present study compared 28 major chemical variables and SQI between waste leachate-affected soils and control soils using four models (e.g., IQI-TDS, IQI-MDS, NQI-TDS, and NQI-MDS) in an agricultural calcareous ecosystem. The leak of the leachate into soil increased the majority of soil variables mainly EC, SAR, ESP, total $\mathrm{N}$, available $\mathrm{P}$ and $\mathrm{K}$, exchangeable cations, and the available and total fractions of heavy metals significantly. Among the 28 variables included in the TDS approach, five soil variables (EC, OM, total Zn, SAR, and exchangeable $\mathrm{Ca}$ ) were selected to the MDS approach using principal components analysis. This show a drop of more than $80 \%$ in total soil variables using the MDS approach, which can cut economic costs and improve work output. The contents of IQI and NQI were dropped by $5-16 \%$ and $6.5-13 \%$ for the TDS approach and by $5-15.2 \%$ and $7.5-12.2 \%$ for the MDS approach after the leak of the leachate into the soils. This implies that the leachate aggravates degradation and deterioration of soil quality. Therefore, new strategies and techniques are required to design appropriate management practices for leachate collection and inhibition of its movement through the development of new dumping sites with a proper foundation. Based on the comparison and evaluation of the accuracy of the different IQI models applied in the study, the data suggested that the IQI-MDS is an optimal model to assess soil quality and predict crop yield. However, we believe that the data need to be evaluated in other regions and ecosystems because they may be site-specific.

Received: 30 October 2020; Accepted: 17 May 2021

Published online: 31 May 2021

\section{References}

1. Kaza, S., Yao, L., Bhada-Tata, P. \& Van Woerden, F. What a waste 2.0: A global snapshot of solid waste management to 2050. https:// openknowledge.worldbank.org/handle/10986/2174 (World Bank Publications, 2018).

2. Rezapour, S., Samadi, A., Kalavrouziotis, I. K. \& Ghaemian, N. Impact of the uncontrolled leakage of leachate from a municipal solid waste landfill on soil in a cultivated-calcareous environment. Waste Manag. 82, 51-61 (2018).

3. Naveen, B. P., Mahapatra, D. M., Sitharam, T. G., Sivapullaiah, P. V. \& Ramachandra, T. V. Physico-chemical and biological characterization of urban municipal landfill leachate. Environ. Pollut. 220, 1-12 (2017).

4. Arunbabu, V., Indu, K. S. \& Ramasamy, E. V. Leachate pollution index as an effective tool in determining the phytotoxicity of municipal solid waste leachate. Waste Manag. 68, 329-336 (2017).

5. Gu, N., Liu, J., Ye, J., Chang, N. \& Li, Y. Y. Bioenergy, ammonia and humic substances recovery from municipal solid waste leachate: A review and process integration. Bioresour. Technol. 293, 122159 (2019).

6. Brady, N. C. \& Weil, R. R. The nature and properties of soils (Pearson, 2016).

7. Ditzler, C. A. \& Tugel, A. J. Soil quality field tools. Agron. J. 94, 33-38 (2002)

8. Andrews, S. S., Karlen, D. L. \& Cambardella, C. A. The soil management assessment framework: A quantitative soil quality evaluation method. Soil Sci. Soc. Am. J. 68, 1945-1962 (2004).

9. Lu, X., Zhang, Y., Lin, Y., Zhang, S. \& Zhao, Q. Island soil quality assessment and the relationship between soil quality and land-use type/topography. Environ. Monit. Assess. 191(4), 230 (2019). 
10. Biswas, S. et al. Establishment of critical limits of indicators and indices of soil quality in rice-rice cropping systems under different soil orders. Geoderma 292, 34-48 (2017).

11. Li, P. et al. Soil quality assessment of wheat-maize cropping system with different productivities in China: Establishing a minimum data set. Soil Till. Res. 190, 31-40 (2019).

12. Askari, M. S. \& Holden, N. M. Indices for quantitative evaluation of soil quality under grassland management. Geoderma 230-231, $131-142(2014)$

13. Santos-Francés, F., Martínez-Graña, A., Ávila-Zarza, C., Criado, M. \& Sánchez, Y. Comparison of methods for evaluating soil quality of semiarid ecosystem and evaluation of the effects of physico-chemical properties and factor soil erodibility (Northern Plateau, Spain). Geoderma 354, 113872 (2019).

14. Mukherjee, A. \& Lal, R. Comparison of soil quality index using three methods. PLoS ONE 9(8), e105981 (2014).

15. Sione, S. M. J., Wilson, M. G., Lado, M. \& González, A. P. Evaluation of soil degradation produced by rice crop systems in a Vertisol, using a soil quality index. CATENA 150, 79-86 (2017).

16. Jahany, M. \& Rezapour, S. Assessment of the quality indices of soils irrigated with treated wastewater in a calcareous semi-arid environment. Ecol. Ind. 109, 105800 (2020).

17. IUSS Working Group. WRB. World reference base for soil resources. World Soil Resources Report. No. 103 (FAO, 2014).

18. Sparks, D.L. et al. Methods of soil analysis, part 3. Chemical methods, 1085-1121 (1996).

19. Bremner, J. \& Mulvaney C. Nitrogen-total. Methods of Soil Analysis. Part 2. Chemical and Microbiological Properties, 595-624 (American Society of Agronomy-Soil Science Society of America, 1982).

20. Olsen, S. R. \& Sommers, L. E. Phosphorus. Methods of Soil Analysis. Part 2. Chemical and Microbiological Properties, 1035-1049 (American Society of Agronomy-Soil Science Society of America, 1982).

21. Thomas, G. W. Exchangeable cations. In Methods of Soil Analysis, Part 2 (ed. Page, P. L.) 159-166 (American Society of Agronomy, 1982).

22. US Salinity Laboratory. Saturated soil paste. Diagnosis and improvement of saline and alkali soils. Agr. Handbook 60 (USDA, 1954).

23. Lindsay, W. L. \& Norvell, W. A. Development of DTPA soil test method for Zn, Fe, Mn and Cu. Soil Sci. Soc. Am. J. 42, 421-428 (1978).

24. Soon, Y. R. \& Abboud, S. Cadmium, chromium, and nickel. In Soil Sampling and Methods of Soil Analysis (ed. Carter, M. R.) 101-108 (Lewis Publishers, 1993).

25. Doran, J. W. \& Parkin, B. T. Defining and assessing soil quality. In Defining Soil Quality for a Sustainable Environment (eds Doran, J. W. et al.) 3-21 (Soil science Society of America, Inc., 1994, Special Publication. Number 35).

26. Qin, M. Z. \& Zhao, J. Strategies for sustainable use and characteristics of soil quality changes in urban-rural marginal area: A case study of Kaifeng. Acta Geograph. Sin. 55, 545-554 (2000) (In Chinese with English abstract).

27. Masto, R. E., Chhonkar, P. K., Purakayastha, T. J., Patra, A. K. \& Singh, D. Soil quality indices for evaluation of long-term land use and soil management practices in semi-arid sub-tropical India. Land Degrad. Dev. 19(5), 516-529 (2008).

28. Somani, M., Datta, M., Gupta, S. K., Sreekrishnan, T. R. \& Ramana, G. V. Comprehensive assessment of the leachate quality and its pollution potential from six municipal waste dumpsites of India. Bioresour. Technol. Rep. 6, 198-206 (2019).

29. Kaur, R. \& Rani, R. Spatial characterization and prioritization of heavy metal contaminated soil-water resources in peri-urban areas of National Capital Territory (NCT), Delhi. Environ. Monit. Assess. 123, 233-247 (2006).

30. Massas, I., Ehaliotis, C., Gerontidis, S. \& Sarris, E. Elevated heavy metal concentrations in top soils of an Aegean island town (Greece): Total and available forms, origin and distribution. Environ. Monit. Assess. 151, 105-116 (2009).

31. Ramos-Miras, J. J., Roca-Perez, L., Guzmán-Palomino, M., Boluda, R. \& Gil, C. Background levels and baseline values of available heavy metals in Mediterranean greenhouse soils (Spain). J. Geochem. Explor. 110(2), 186-192 (2011).

32. Chiwetalu, U. J., Mbajiorgu, C. C. \& Ogbuagu, N. J. Remedial ability of maize (Zea mays) on lead contamination under potted condition and non-potted field soil condition. J. Bioresour. Bioprod. 5(1), 51-59 (2020).

33. Krčmar, D. et al. Preremedial assessment of the municipal landfill pollution impact on soil and shallow groundwater in Subotica, Serbia. Sci. Total Environ. 615, 1341-1354 (2018).

34. Liu, C. et al. Soil heavy metal pollution assessment near the largest landfill of China. Soil Sediment Contam. Int. J. 22(4), 390-403 (2013).

35. Adamcová, D. et al. Environmental assessment of the effects of a municipal landfill on the content and distribution of heavy metals in Tanacetum vulgare L. Chemosphere 185, 1011-1018 (2017).

36. Singh, A. K., Bordoloi, L. J., Kumar, M., Hazarika, S. \& Parmar, B. Land use impact on soil quality in eastern Himalayan region of India. Environ. Monit. Assess. 186(4), 2013-2024 (2014).

37. Basak, N. et al. Assessing soil quality indices for sub-tropical rice-based cropping systems in India. Soil Res. 54, 20-29. https://doi. org/10.1071/SR14245 (2015)

38. Nabiollahi, K., Golmohamadi, F., Taghizadeh-Mehrjardi, R., Kerry, R. \& Davari, M. Assessing the effects of slope gradient and land use change on soil quality degradation through digital mapping of soil quality indices and soil loss rate. Geoderma 318, 16-28 (2018).

39. Zeraatpisheh, M., Bakhshandeh, E., Hosseini, M. \& Alavi, S. M. Assessing the effects of deforestation and intensive agriculture on the soil quality through digital soil mapping. Geoderma 363, 114139 (2020).

40. Ghosh, P. \& Thakur, I. S. An integrated approach to study the risk from landfill soil of Delhi: Chemical analyses, in vitro assays and human risk assessment. Ecotoxicol. Environ. Saf. 143, 120-128 (2017).

41. Wei, Y. et al. Environmental challenges impeding the composting of biodegradable municipal solid waste: A critical review. Resour. Conserv. Recycl. 122, 51-65 (2017).

42. Ma, W. et al. Contamination source apportionment and health risk assessment of heavy metals in soil around municipal solid waste incinerator: A case study in North China. Sci. Total Environ. 631, 348-357 (2018).

43. Imaz, M. J. et al. Soil quality indicator response to tillage and residue management on semi-arid Mediterranean cropland. Soil Till. Res. 107(1), 17-25 (2010).

44. Li, X., Wang, D., Ren, Y., Wang, Z. \& Zhou, Y. Soil quality assessment of croplands in the black soil zone of Jilin Province, China: Establishing a minimum data set model. Ecol. Ind. 107, 105251 (2019).

45. Karlen, D. L., Andrews, S. S., Wienhold, B. J. \& Zobeck, T. M. Soil quality assessment: Past, present and future. Electron. J. Integr. Biosci. 6, 3-14 (2008).

46. De Clerck, F., Singer, M. J. \& Lindert, P. A 60-year history of California soil quality using paired samples. Geoderma 114(3-4), 215-230 (2003).

47. Samadder, S. R., Prabhakar, R., Khan, D., Kishan, D. \& Chauhan, M. S. Analysis of the contaminants released from municipal solid waste landfill site: A case study. Sci. Total Environ. 580, 593-601 (2017).

48. Rezapour, S., Taghipour, A. \& Samadi, A. Modifications in selected soil attributes as influenced by long-term continuous cropping in a calcareous semiarid environment. Nat. Hazards 69(3), 1951-1966 (2013).

49. Bhardwaj, A. K., Jasrotia, P., Hamilton, S. K. \& Robertson, G. P. Ecological management of intensively cropped agro-ecosystems improves soil quality with sustained productivity. Agric. Ecosyst. Environ. 140, 419-429 (2011).

50. Vasu, D. et al. Soil quality index (SQI) as a tool to evaluate crop productivity in semi-arid Deccan plateau, India. Geoderma 282, 70-79 (2016). 
51. de Paul Obade, V. \& Lal, R. Towards a standard technique for soil quality assessment. Geoderma 265, 96-102 (2016).

52. Mukhopadhyay, S. et al. Soil quality index for evaluation of reclaimed coal mine spoil. Sci. Total Environ. 542, 540-550 (2016).

53. Raiesi, F. A minimum data set and soil quality index to quantify the effect of land use conversion on soil quality and degradation in native rangelands of upland arid and semiarid regions. Ecol. Ind. 75, 307-320 (2017).

54. Karkaj, E. S., Sepehry, A., Barani, H., Motamedi, J. \& Shahbazi, F. Establishing a suitable soil quality index for semi-arid rangeland ecosystems in northwest of Iran. J. Soil Sci. Plant Nutr. 19(3), 648-658 (2019).

55. Qi, Y. et al. Evaluating soil quality indices in an agricultural region of Jiangsu Province, China. Geoderma 149, 325-333 (2009).

56. Zhang, W., Hu, J., Yang, Y. \& Lin, Y. One compound approach combining factor-analytic model with AMMI and GGE biplot to improve multi-environment trials analysis. J. For. Res. 31(1), 123-130 (2020).

\section{Acknowledgements}

The authors wish to thank Urmia University (Grant Number: 2556) for financial support of the present study.

\section{Author contributions}

S.Y. helped in soil analysis and determination of soil heavy metals. S.R. designed the study and set up the field work and experiments. F.A. designed tables and graphs and conducted statistical analysis. Research write up was carried out by S.R. All authors reviewed the manuscript.

\section{Competing interests}

The authors declare no competing interests.

\section{Additional information}

Supplementary Information The online version contains supplementary material available at https://doi.org/ 10.1038/s41598-021-90699-1.

Correspondence and requests for materials should be addressed to S.R.

Reprints and permissions information is available at www.nature.com/reprints.

Publisher's note Springer Nature remains neutral with regard to jurisdictional claims in published maps and institutional affiliations.

(c) (i) Open Access This article is licensed under a Creative Commons Attribution 4.0 International License, which permits use, sharing, adaptation, distribution and reproduction in any medium or format, as long as you give appropriate credit to the original author(s) and the source, provide a link to the Creative Commons licence, and indicate if changes were made. The images or other third party material in this article are included in the article's Creative Commons licence, unless indicated otherwise in a credit line to the material. If material is not included in the article's Creative Commons licence and your intended use is not permitted by statutory regulation or exceeds the permitted use, you will need to obtain permission directly from the copyright holder. To view a copy of this licence, visit http://creativecommons.org/licenses/by/4.0/.

(C) The Author(s) 2021 